\title{
Forensic Nursing in Humanitarian Forensics
}

\author{
Rakesh K Gorea \\ Professor Emeritus, JJT University, Rajasthan, India \& Professor and Head, Forensic Medicine, Gian Sagar Medical College, Ram \\ Nagar, Rajpura, Patiala, India
}

\begin{abstract}
Humanitarian forensics has been established as a new entity, and it is bound to develop as a robust branch of science. It is a multidisciplinary subject with the involvement of experts from different fields of science. Forensic nursing too is an upcoming branch of nursing science and is a relatively new discipline of science. Forensic nursing science is expanding in various countries. This paper will describe and discuss the various important aspects of Humanitarian forensics and forensic nurses' utility in humanitarian forensics and discuss the future role of forensic nurses in humanitarian forensics.

Keywords: DVI, Forensic Nursing, Humanitarian Forensics, Socio-cultural crimes.

Int J Eth Trauma Victimology (2020). DOI: 10.18099/ijetv.v6i02.1
\end{abstract}

\section{INTRODUCTION}

11 - 0 orensic nursing science is a branch of science which is a combination of knowledge and the practice of nursing health care, the criminal justice system and Forensic Sciences including Forensic Medicine; when applied to criminal investigation and judicial system of a country."1

Forensic nursing is now gradually making its presence felt in the different countries with the coordinated activities of different organizations like the International Association of Forensic Nurses [IAFN], ${ }^{2}$ Indo Pacific Academy of Forensic Nursing Science [INPAFNUS], ${ }^{3}$ American Forensic Nurses Association [AMRN], ${ }^{4}$ American Association of Legal nurse consultants [AALNC], ${ }^{5} \mathrm{UK}$ association of forensic Nurses [UKAFN], ${ }^{6}$ and Forensic Nurses Association of Canada [FNAC]. ${ }^{7}$

Suppose we see the origin of Forensic nursing. In that case, it can be traced to the United Kingdom in 1950, and stronger evidence of this practice was providing care to the persons in custody who needed mental health care or were involved with psychotropic substances in $1979 .{ }^{8}$ In the USA, forensic nursing initiated counseling of victims of sexual assault in 1976 at Yale-New Haven Hospital. ${ }^{9}$ It was recognized as a specialty due to the consistent efforts of Virginia A Lynch in $1980 .{ }^{10}$ Now, this has extended to many other countries. ${ }^{11}$ Forensic nursing science is scheduled to be part of the undergraduate nursing course in India, and post graduate (PG) course is being run by the Gujarat Forensic Science University. ${ }^{1}$

Humanitarian forensic science is the application of the forensic sciences to humanitarian purposes so that with their skills and knowledge, they can benefit humanity. This is commonly being applied to the aftermath of conflicts and disasters. ${ }^{12}$ It alleviates the sufferings of humans. ${ }^{13}$

Its actions dates back to the $2^{\text {nd }}$ world war when identification was provided to the buried persons after examination of their documents and reburies in the named graves. ${ }^{13}$

Forensic humanitarians took its shape in 2000 when the International Red Cross society started taking help for the
Corresponding Author: Dr. Rakesh K Gorea, Professor Emeritus, JJT University, Rajasthan, India \& Professor and Head, Forensic Medicine, Gian Sagar Medical College, Ram Nagar, Rajpura, Patiala, India, e-mail: gorea_r@yahoo.com

How to cite this article: Gorea RK. Forensic Nursing in Humanitarian Forensics. Int J Eth Trauma Victimology. 2020;6(2): 1-5.

Source of support: Nil

Conflict of interest: None declared

forensic scientists for its activities through it initiated in 1980 after the end of the War of Argentina and strengthened by the end of Yugoslavia in $1990 .{ }^{13}$ To identify the dead body in armed conflicts became important in 1996 with the passage of the resolution by the Interpol Standing Committee on Disaster Victim Identification. ${ }^{14}$ To give dignity and identification to the dead bodies in mass disasters or wars International Society of the Red Cross started Humanitarian Forensic Action. It worked in Haiti's 2010 earthquake with 230000 deaths, in Super Typhoon Haiyan in the Philippines in 2013, Falkland in 2016, in 2019 in Mozambique's 2019 typhoon involving the death of 1000 persons. $^{15}$

Disasters maybe natural, manmade or hybrid. ${ }^{16}$ Natural disasters usually cause havoc e.g. floods, earthquakes, landslides avalanches and storms. Manmade disasters are due to the activity of human beings or their negligence e.g. terrorist activities. Hybrid disasters are due to activities of man which increases the effects of natural phenomenon and all types of disasters need warning and management system. ${ }^{17}$

Humanitarian Forensics works under the International Humanitarian Laws ${ }^{18}$ rather than the local laws of the country. When there is a mass disaster it may be a challenge for the local authorities to identify and dispose of the dead bodies in a dignified way. ${ }^{15,19}$

The interaction with the victims and families of the bereaved persons is very important and will determine the 
success or failure of the cases. ${ }^{13}$ Providing comfort and information to the relatives of the missing persons is one of the main objectives of forensic humanitarian forensics as the interviewer is the forensic persons. ${ }^{20}$ The family members and friends have the right to know about the dead persons and this can be done by the examination of the remains of the dead bodies. ${ }^{21}$

Maintaining human dignity is very important for optimum results whether it may be dealing with survivors or their family members. All such people need psychological support. Investigating people must understand that such individuals have rights and they have the right to make decisions and right to elaborate during giving of the histories, which should be respected. Psychological support and pysho-social commitment help in the healing process. ${ }^{22}$

Other goals of humanitarian forensics are estimating the individuals' age, document the torture in custodial settings, monitor the places of detention, and manage hunger strikes. ${ }^{13}$ There is a need to understand that social and cultural beliefs may be behind the crime. It needs to be tackled and humanitarian forensics may be able to interact and help reduce the crimes. ${ }^{23}$ As people are migrating from one country to the other, the socio-cultural values are shifting and so are shifting the crimes and are not just limited to the one country. ${ }^{24}$

In epidemics like Ebola too forensic humanitarian activities can be very useful by giving dignity to the dead bodies. People usually do not come forward for the final rites of the dead body. Proper disposal of the dead bodies can help in preventing the spread of the epidemics. ${ }^{20}$ A total of 45 unsafe burials were reported in a paper, and on an average seven people were associated with each unsafe burial and $65 \%$ of such contacts became sick afterwards. Safe and dignified burial in Ebola epidemics limits the spread of the disease in epidemics. ${ }^{25}$ Similarly, the dead body's safe disposal can also prevent the spread of COVID 19 and give dignity to the dead bodies. ${ }^{26}$

There are victims of torture which may be victims of torture due to activities by terrorists or action by investigation agencies or security forces. Triad of blunt trauma i .e. bruises, patterned injuries and internal injuries; electrical and thermal injuries and injuries from prolonged suspension, which causes stress on the body. Due to this prolonged hanging stress, there occurs necrosis of muscles resulting in myoglobinuric renal failure and death. This may remain obscure until a proper autopsy is done especially of muscles of back, shoulder and knee joints and soles. ${ }^{27}$

In terrorists' incidences identification of the terrorists is also facilitated by international coordination. ${ }^{28}$ The pattern of injuries in surrendered terrorists may indicate they may have been killed e.g. firearm injuries and blunt trauma with opposing trajectories. ${ }^{29}$

Survivors of sexual assaults can be benefitted by the domain of forensic humanitarian forensics. It needs a planned approach which is usually a multidisciplinary approach, and if provided in a timely manner can be very fruitful. Religious and cultural values of the victims must be respected when dealing with gender-based violence. ${ }^{30}$
Trafficking of children is a serious issue affecting the rights of children and such child victims need to be identified. Mostly such children have a history of abuse, and such children should be removed from their sufferings and given a life of dignity and saved by ascertaining their identity so that they can be located and sent back to their families and rehabilitated. Those responsible for these crimes should be punished and compensation may be given to such children. ${ }^{31}$

Dignity of the dead is important so the dead bodies should be disposed of in a dignified way and one of the main step in the management of the dead. ${ }^{32}$ Various guidelines have been developed for the forensic pathologists to deal with the dead bodies in mass disasters- Interpol DVI Guide. ${ }^{33}$ Four steps are highlighted for identification i.e. crime scene investigation; Postmortem data comprising of fingerprints, dental examination, DNA profiling and physical examination; antemortem data and reconciliation of PM data with antemortem data. ${ }^{28}$

There are other guidelines too like "United Nations Manual on The Effective Prevention and Investigation of Extra-Legal, Arbitrary and Summary Executions, U.N. (1991)"34 and "The Minnesota Protocol on the Investigation of Potentially Unlawful Death 2016". ${ }^{35}$

International coordination in situations of disasters definitely improves the process of identification of the victims of disasters. ${ }^{28}$ Persons with the right skills need to be identified as per DVI Guide ${ }^{33}$ and forensic nurses have the right skills which can be utilized in such scenarios. There is an international commission on missing persons, and missing persons can be reported to the commission and they try to find that missing persons and forensic persons can submit their findings in a case to them. It has helped by identifying $70 \%$ of the missing persons in Yugoslavia. ${ }^{36}$

In the case of missing persons, there may be multiple challenges, and all of them need to be tackled. The number of missing persons needs to be determined, and their identity needs to be established. Working protocols, a form of investigation as multiple stakeholders may be involved, need to address the cultural beliefs of the missing persons. All this has to do with time and funds constraints and keeping in mind the political establishment of that country where the investigation is being held. ${ }^{37}$

The DNA profiling and DNA databank can be very useful in identifying missing persons ${ }^{38}$ Internationally accepted guidelines are lacking though Interpol guidelines are being applied at many places. ${ }^{38}$ Statistical support about DNA markers of various communities is also non-existent, and there is a need to accept the lineage markers Y chromosome polymorphism and mitochondrial DNA for identification of parental lineage. ${ }^{39}$

The DVI work is affected by many factors. One of the factors is if the dead body is the sea. People try to migrate through sea and accidents do happen and deaths occur. Identification in such situations may be really troublesome. Temperature, depth, salinity, currents and oxygen levels of 
water may affect identification and factors like wearing of clothes, the stature of the person and status whether alive or dead when submerged in water and all these affect the retrieval of the dead bodies. ${ }^{40}$ In one of Italy's studies about migrants in the Mediterranean Sea, $60 \%$ of such persons got buried in a stage of unidentified. The government and its various organizations are combining the services of Medico-legal, anthropological, forensic odontological, and forensic genetic services to identify the deceased persons. ${ }^{39}$

Data management for DVI is also very important and involves collecting (antemortem and Post-mortem data) and archiving data, comparison, and analysis, and then reporting. ${ }^{41}$

Procedure of prevention, investigation and documentation of torture in the form of psychological and physical injuries in custodial places is mentioned in the UN manual and forensic science and forensic medicine play an important role in it. ${ }^{42,43}$

According to the Declaration of Basic Principals of Justice for victims of crime and abuse of power, standards have been set for the victims' rights and protection. According to this access to the fair Justice access to treatment, restitution, compensation, and assistance have been identified. ${ }^{44}$ But victims are not being treated with dignity and are not protected from intimidation. ${ }^{45}$ Even rights have been given to the detainees for which officials have to take care to provide these rights e.g., Right to physical and moral integrity, right to an adequate standard of living, health rights of prisoners, making prisons safe places, making the best use of prisons, prisoners' contact with the outside world, complaints and inspection procedures. ${ }^{46}$

Rights have been given to all persons that they will not be tortured under any circumstances will not be given any degrading treatment according to the Universal Declaration of Human rights. ${ }^{47}$ Jail officials have been barred from this and in case of such treatment to the inmates, jail officials can be in trouble. ${ }^{46}$

The capacity building of each nation for the DVI is very important, and in many circumstances, there is a need for exhumations and excavations. For the programs to succeed in local responsibility and local ownership of the mechanism is very important. ${ }^{48}$

Forensic nurses are part of the death investigation in many areas. They mix their nursing education with criminology, law, and Forensic Medicine to help the investigation teams by carefully planning, going to the crime scene, observing and evaluating the crime scene. ${ }^{49-51}$ The trained forensic physician may not always be available, and then a forensic nurse death investigator may be ideal in such situations, and forensic nurses are being utilized in many counties in the USA. ${ }^{50}$ They are being posted as coroner, deputy coroner, death investigator, and nurse investigator to perform this role. ${ }^{52}$

Forensic nurses are being utilized in mass disasters and situations of community crisis ${ }^{8}$ and can be very well utilized in humanitarian forensic work.

There are online courses for Professional Certificate in Nurse Death Investigation. The nurses learn to collect the evidence at the crime scene, which is important for the case, and then preserve the evidence. They also are trained to photograph the crime scene and how everything is documented. They are also taught how to do the dissection of the dead body. They also look for the identification of the dead. They are also taught to look for the various signs of death and how they proceed with the time elapsed after death. ${ }^{51}$

The forensic nurses' attitude affects the intervention, optimism, and not to perform in a stereotype working in substance user services, ${ }^{53}$ and this may be equally true for the forensic nurses in humanitarian forensic work. To succeed, forensic nurses also need effective and excellent written and verbal communication to deal with the victims, offenders, police officials and team members. ${ }^{54}$ Violence survivors and victim advocates may have conflicts with the team members because advocates usually use indirect communication language whereas forensic nurses usually use direct communication languages, and good communication skills can effectively tackle these. ${ }^{55}$

\section{Materials and Methods}

Google Search and Google Scholar search using the keywords were used, and the relevant articles were selected.

\section{Discussion}

Humanitarian forensics is the branch of science that involves using forensic science for humanitarian purposes. It may be the identification of victims of mass disasters or identification of missing persons after a war or identification of victims of war and epidemics.

Role of nurses for humanitarian purposes goes back to the origin of nursing when the founder of modern nursing Florence Nightingale the British nurse in $18^{\text {th }}$ century was taking care of victims of war in the Crimean war ${ }^{56}$ or Bhai Kanhaiya was giving water to the war victims earlier to the origin of nursing in the $17^{\text {th }}$ century. ${ }^{57}$

It also helps identify and prosecute the victims of sociocultural crimes, including religious crimes.

Forensic nurses can help in photographic documentation of the injuries when a forensic pathologist is documenting these injuries in the medico-legal reports.

Forensic nurses can provide the right type of psychological support to the victims of torture and their families and families of the missing persons.

Forensic nurses can interview the victims of torture in a very compassionate manner, which is an essential aspect of DVI. Attitude and communication skills can play a very important role during interviews to elicit information from the victims which may be very useful for the case.

Autopsy in torture related deaths is important to find out the signs of torture and find out the injuries and find out the exact cause of death, which may be missed in a routine autopsy.

\section{Conclusion}

Forensic nurses can play a vital role in humanitarian forensics. They can play a crucial role in documentation and providing 
psychological support as they are experts in dealing with the victims and their families. They can provide psychological support even to the team members. They can help in preventing the spread of epidemics and take care of forensic aspects when there are several deaths due to epidemics. When there is a shortage of forensic physicians, they can fill the gap in humanitarian forensic work. They can play a perfect role in disasters, whether it is human-made or it is natural. This discipline requires further research and development, and ultimately forensic nurses will be able to contribute significantly in humanitarian forensics. Forensic nurses should be a part of the humanitarian forensic teams. The attitude of the forensic nurses who wish to work in humanitarian forensics should be optimum as suboptimum attitudes will not bring the desired success rates. Forensic nurses need to have effective communication skills to be successful in humanitarian forensic work.

\section{REFERENCES}

1. Introduction and Development of Forensic Nursing science $\mid$ Prof (Dr) Rakesh Kumar Gorea [Internet]. 2020 [cited 2020 Jul 18]. Available from: https://www.youtube.com/watch?v=vdBDHsC AQCE\& feature $=$ youtu.be

2. International Association of Forensic Nurses [Internet]. [cited 2020 Jul 18]. Available from: https://www.forensicnurses.org/

3. Forensicwayout [Internet]. [cited 2020 Jul 18]. Available from: http://inpafnus.forensicwayout.org/

4. American Forensic Nurses, AMRN [Internet]. [cited $2020 \mathrm{Jul}$ 18]. Available from: http://amrn.com/faq.html

5. AALNC : American Association of Legal Nurse Consultants [Internet]. [cited $2020 \mathrm{Jul}$ 20]. Available from: http://www. aalnc.org/

6. UKAFN.org - The UK Association of Forensic Nurses \& Paramedics [Internet]. [cited 2020 Jul 20]. Available from: https://ukafn.org/

7. About [Internet]. Canadian Forensic Nurses Association. [cited $2020 \mathrm{Jul}$ 20]. Available from: https://forensicnurse.ca/about/

8. Scannell MJ. History of Forensic Nursing [Internet]. Springer Publishing Company; 2020 [cited 2020 Jul 20]. Available from: https://connect.springerpub.com/content/book/978-0-82613867-5/part/part01/chapter/ch01

9. Clark TP. Counseling Victims of Rape. Am J Nurs. 1976;76(12):1964-1966.

10. Lynch A, Duval J. Forensic nursing science: 2 nd ed. St. Louis, MO: Mosby/Elsevier; 2011.

11. Forensic nursing science: Global strategies in health and justice | Elsevier Enhanced Reader [Internet]. [cited 2020 Jul 20]. Available from: https://reader.elsevier.com/reader/sd/pii/S209 0536X11000049?token=3BE3725CB2AD5E5B3582917D3CFF EF4B498D3000A5178CA5122CF957996903348D1F08A5B158 F49E17A5F5213B55499B

12. Cordner S. Humanitarian forensic science. Aust J Forensic Sci. 2018 Nov 2;50(6):639-650.

13. Cordner S, Tidball-Binz M. Humanitarian forensic action - Its origins and future. Forensic Sci Int. 2017 Oct;279:65-71.

14. pdf.pdf [Internet]. [cited 2020 Jul 22]. Available from: https:// www.legal-tools.org/doc/d6aa95/pdf/

15. Samarji A, Shokry D. Humanitarian forensic scientists trace the missing, identify the dead and comfort the living [Internet].
The Conversation. [cited $2020 \mathrm{Jul}$ 21]. Available from: http://theconversation.com/humanitarian-forensic-scientiststrace-the-missing-identify-the-dead-and-comfort-the-living115623

16. Mohamed Shaluf I. Disaster types. Disaster Prev Manag Int J. 2007 Jan 1;16(5):704-717.

17. Natural and Hybrid Disasters - Causes, Effects, and Management [Internet]. [cited $2020 \mathrm{Jul} 23$ ]. Available from: //www. nursingcenter.com/journalarticle?Article_ID $=462689 \&$ Journal_ ID $=420955 \&$ Issue_ID $=462686$

18. International humanitarian law |Weapons Law Encyclopedia [Internet]. [cited $2020 \mathrm{Jul}$ 21]. Available from: http://www. weaponslaw.org/glossary/international-humanitarian-law-ihl

19. 1949 Geneva Conventions | Weapons Law Encyclopedia [Internet]. [cited $2020 \mathrm{Jul}$ 21]. Available from: http://www. weaponslaw.org/instruments/1949-geneva-conventions

20. Thomsen JL. Ethical considerations for forensic scientists participating in humanitarian action: A personal reflection. Forensic Sci Int. 2017 Sep 1;278:379-380.

21. Gaggioli G. International Humanitarian Law: The legal framework for humanitarian forensic action. Forensic Sci Int. 2018 Jan 1;282:184-194.

22. Hofmeister U, Navarro S. A psychosocial approach in humanitarian forensic action: The Latin American perspective. Forensic Sci Int. 2017 Nov 1;280:35-43.

23. Lawson T, Heaton T. Socio-cultural explanations of crime and deviance. In: Lawson T, Heaton T, editors. Crime and Deviance [Internet]. London: Macmillan Education UK; 1999 [cited 2020 Jul 23]. p. 47-89. (Skills-Based Sociology). Available from: https://doi.org/10.1007/978-1-349-14035-0_3

24. Gorea R. Sociocultural crimes: a forensic approach. In: Forensic Nursing Science. 2nd ed. SL Missouri: Elsevier Mosby; 2011. p. 497-511.

25. Tiffany A, Dalziel BD, Kagume Njenge H, Johnson G, Nugba Ballah R, James D, et al. Estimating the number of secondary Ebola cases resulting from an unsafe burial and risk factors for transmission during the West Africa Ebola epidemic. PLoS Negl Trop Dis. 2017;11(6):e0005491.

26. Manoj M. COVID-19: General Guidance for the Management of the Dead [Internet]. Humanitarian Library. 2020 [cited 2020 Aug 14]. Available from: https://www.humanitarianlibrary.org/ resource/covid-19-general-guidance-management-dead

27. Pollanen MS. The pathology of torture. Forensic Sci Int. 2018 Mar;284:85-96.

28. Disaster Victim Identification (DVI) [Internet]. [cited $2020 \mathrm{Jul}$ 18]. Available from: https://www.interpol.int/en/How-we-work/ Forensics/Disaster-Victim-Identification-DVI

29. Baraybar JP. A potential contribution to human identification using peri-mortem trauma: An example from Peru. Forensic Sci Int. 2017 Nov 1;280:139-146.

30. Wells D. Sexual violence interventions: Considerations for humanitarian settings. Forensic Sci Int. 2017 Jul 1;276:1-4.

31. Obertová Z, Cattaneo C. Child trafficking and the European migration crisis: The role of forensic practitioners. Forensic Sci Int. 2018 Jan 1;282:46-59.

32. Cordner S, Ellingham STD. Two halves make a whole: Both first responders and experts are needed for the management and identification of the dead in large disasters. Forensic Sci Int. 2017 Oct 1;279:60-64.

33. Disaster Victim Identification Guide. Interpol;

34. UN_Manual_on_the_Effective_Prevention_and_ Investigation[1].pdf [Internet]. [cited 2020 Jul 18]. Available 
from: https://www.un.org/ruleoflaw/files/UN_Manual_on_the Effective_Prevention_and_Investigation\%5B1\%5D.pdf

35. United Nations. The Minnesota Protocol on the Investigation of Potentially Unlawful Death 2016: The Revised United Nations Manual on the Effective Prevention and Investigation of ExtraLegal, Arbitrary and Summary Executions [Internet]. UN; 2018 [cited 2020 Jul 18]. Available from: https://www.un-ilibrary.org/ human-rights-and-refugees/the-minnesota-protocol-on-theinvestigation-of-potentially-unlawful-death-2016_0389ae17-en

36. ICMP International Commission on Missing Persons [Internet]. [cited $2020 \mathrm{Jul}$ 22]. Available from: https://www.icmp.int/

37. Salado Puerto M, Tuller H. Large-scale forensic investigations into the missing: Challenges and considerations. Forensic Sci Int. 2017 Oct 1;279:219-228.

38. Goodwin WH. The use of forensic DNA analysis in humanitarian forensic action: The development of a set of international standards. Forensic Sci Int. 2017 Sep 1;278:221-227.

39. Challenges in the identification of dead migrants in the Mediterranean: The case study of the Lampedusa shipwreck of October 3rd 2013. Forensic Sci Int. 2018 Apr 1;285: $121-128$.

40. Ellingham S, Perich P, Tiddbal-Binz M. The fate of human remains in a maritime context and feasibility for forensic humanitarian action to assist in their recovery and identification. Forensic Sci Int. 2017 Oct 1;279:229-234.

41. Hofmeister U, Martin SS, Villalobos C, Padilla J, Finegan O. The ICRC AM/PM Database: Challenges in forensic data management in the humanitarian sphere. Forensic Sci Int. 2017 Oct 1;279:1-7.

42. ARTIP - Short Summary [Internet]. [cited 2020 Jul 22]. Available from: http://www.istanbulprotocol.info/index.php/en/shortsummary

43. United Nations, editor. Istanbul Protocol: manual on the effective investigation and documentation of torture and other cruel, inhuman, or degrading treatment or punishment. Rev. 1. New York: United Nations; 2004. 76 p. (Professional training series).

44. Muralidhan S. Rights of Victims in the Indian Criminal Justice System.:14.

45. Rights of Victims of Crime - Need for a Fresh Look: Justice Anand | National Human Rights Commission India [Internet]. [cited 2020 Jul 23]. Available from: https://nhrc.nic.in/pressrelease/rights-victims-crime-need-fresh-look-justice-anand
46. United Nations, editor. Human rights and prisons: a pocketbook of international human rights standards for prison officials. New York ; Geneva: Office of the United Nations High Commissioner for Human Rights; 2005. 34 p. (Professional training series).

47. Universal Declaration of Human Rights [Internet]. 2015 [cited $2020 \mathrm{Jul}$ 23]. Available from: https://www.un.org/en/universaldeclaration-human-rights/

48. Mikellide M. Recovery and identification of human remains in post-conflict environments: A comparative study of the humanitarian forensic programs in Cyprus and Kosovo. Forensic Sci Int. 2017 Oct 1;279:33-40.

49. Examining the role of the forensic nurse death investigator Article | NursingCenter [Internet]. [cited 2020 Jul 19]. Available from: https://www.nursingcenter.com/journalarticle?Article_ ID $=1108846 \&$ Journal ID $=54016 \&$ Issue ID $=1108836$

50. Death Investigation - International Association of Forensic Nurses [Internet]. [cited 2020 Jul 19]. Available from: https:// www.forensicnurses.org/page/DeathInvest

51.webmaster@ucx.ucr.edu SD. Nurse Death Investigation [Internet]. [cited $2020 \mathrm{Jul}$ 19]. Available from: https://www. extension.ucr.edu/certificates/13786704/healthcareandwellness/ professionaldevelopmentfornurses/nursedeathinvestigation

52. Part 2. Inside Forensic Nursing [Internet]. Medscape. [cited 2020 Jul 19]. Available from: http://www.medscape.com/ viewarticle/571555

53. Foster JH, Onyeukwu C. The attitudes of forensic nurses to substance using service users. J Psychiatr Ment Health Nurs. 2003 Oct;10(5):578-584.

54. Forensic Nursing: Communicating in Difficult Situations [Internet]. Duquesne University School of Nursing. 2019 [cited 2020 Jul 21]. Available from: https:/onlinenursing.duq.edu/blog/ forensic-nursing-communicating-in-difficult-situations/

55. Patterson D. Interdisciplinary Team Communication Among Forensic Nurses and Rape Victim Advocates. Soc Work Health Care. 2014 Apr 21;53(4):382-397.

56. Florence Nightingale | Biography \& Facts [Internet]. Encyclopedia Britannica. [cited $2020 \mathrm{Jul}$ 20]. Available from: https://www. britannica.com/biography/Florence-Nightingale

57. Bhai Kanhaiya | Discover Sikhism [Internet]. [cited 2020 Jul 20]. Available from: http://www.discoversikhism.com/sikhs/ bhai_kanhaiya.html 